\title{
Characterization of coronary arteries in Giant Anteater (Myrmecophaga tridactyla: Myrmecophagidae)
}

\author{
[Caracterização da artéria coronária em tamanduá-bandeira (Myrmecophaga tridactyla: \\ Myrmecophagidae)] \\ C.A.T. Cruvinel ${ }^{1}$, T.M.A. Cruvinel $^{2}$, L.P.N. Aires ${ }^{3}$, R.F. Rodrigues ${ }^{5}$, A.P.F. Melo ${ }^{5^{*}}$ \\ ${ }^{1}$ Médico Veterinário autônomo - São José do Rio Preto, SP \\ ${ }^{2}$ Centro Universitário de Rio Preto - São José do Rio Preto, SP \\ ${ }^{3}$ Médico veterinário autônomo - São José do Rio Preto, SP \\ ${ }^{4}$ Universidade Estadual Paulista "Júlio de Mesquita Filho" - Araçatuba,SP \\ ${ }^{5}$ Universidade Estadual Paulista "Júlio de Mesquita Filho" - Ilha Solteira, SP
}

C.A.T. Cruvinel1, https://orcid org/0000-0002-1702-9999 T.M.A. Cruvinel2 https://orcid.org/0000-0001-7430-0290 L.P.N. Aires3, https://orcid.org/0000-0003-3229-9396 R.F. Rodrigues5, https://orcid.org/0000-0003-1836-6628 A.P.F. Melo5* https://orcid.org/0000-0002-8451-6017

\begin{abstract}
Were used twelve (12) adult anteaters (Myrmecophaga tridactyla), adults, 6 (six) males and 6 (six) females, weighing from 20 to $27.32 \mathrm{~kg}$ from free life. The thoracic cavity was opened until visualization of the whole heart and lungs and later injection of the coronary vessels. The right coronary artery emerged through a single coronary ostium of the aorta, 50\%, emitting the intermediate branch and the subsinuous interventricular branch, had a path directed to the subsurface interventricular groove. In the other $50 \%$, the right coronary artery was not present, showing only its branches, intermediate branch and subsurface interventricular branch with emergence of the aorta. Left coronary artery presented, in $83.33 \%$, origin from the aorta in single ostium, issuing the circumflex and interventricular paraconal branches. In $16.66 \%$, the left coronary artery was not evidenced originating from the aorta, but its branches, circumflex and interventricular paraconal.
\end{abstract}

Keywords: heart, coronary artery, wild animals, giant anteaters

\section{RESUMO}

Foram utilizados 12 tamanduás-bandeira (Myrmecophaga tridactyla), adultos, sendo seis machos e seis fêmeas, pesando de 20 a 27,32kg, provenientes de vida livre. Foi realizada abertura da cavidade torácica até a visualização do conjunto coração e pulmões e, posteriormente, injeção dos vasos coronários. A artéria coronária direita emergia, 50\% dela, por um único óstio coronário da aorta, emitindo o ramo intermédio e o ramo interventricular subsinuoso; tinha trajeto direcionado ao sulco interventricular subsinuoso. Nos outros 50\%, a artéria coronária direita não estava presente, exibindo somente seus ramos, ramo intermédio e ramo interventricular subsinuoso com emergência da aorta. A artéria coronária esquerda apresentou, em 83,33\%, origem a partir da aorta em óstio único, emitindo os ramos circunflexo e interventricular paraconal. Em 16,66\%, a artéria coronária esquerda não foi evidenciada originando-se da aorta, mas, sim, de seus ramos, circunflexo e interventricular paraconal.

Palavras-chave: coração, artéria coronária, tamanduá-bandeira

\section{INTRODUCTION}

The heart is an organ with great functional importance, considering that a great amount of the human population suffers from functional problems which might require a transplant or

Recebido em 12 de junho de 2017

Aceito em 17 de abril de 2018

* Autor para correspondência (corresponding author)

E-mail: alan.melo@unesp.br even new experimental and remodeling techniques (Taylor et al., 2007; Copeland et al., 2004; Morgan et al., 2004; Hanes et al., 2015). The organ has a specialized arterial supply, the right and left coronary arteries, which originate from the aorta (Schummer et al., 1981; Ghoshal and Getty, 1986; Ghoshal, 1986, Oliveira, 2013). 
These arteries can vary as to their origin, path and number (Schlesinger et al., 1949; Cervený and Kaman, 1963; Schummer et al., 1981; Ghoshal and Getty, 1986; Vicentini et al., 1991; Valentina et al., 2003; Olabu et al., 2007; Yuan et al., 2009; Agustin et al., 2010, Srour, 2011; Kareem et al., 2014)) and they can be presented completely intramyocardial (Sans Coma et al., 1993 ) or partially (Bezerra et al.,1985 and Machado et al., 2002). In instances where part of the artery is covered by the myocardium, structures called myocardial bridges can be observed and their functions are widely discussed (Berg, 1964 and Corban et al., 2014).

The right and left coronary arteries emerge from the aorta, each one presenting a single coronary ostium (Schummer et al., 1981; Ghoshal and Getty, 1986; Ghoshal, 1986, Valentina et al. 2003 and Oliveira et al., 2013). There are cases in calves and humans with only one coronary artery being responsible for the whole heart's irrigation, presenting only one ostium from the aorta (Cervený and Kaman, 1963 and Koizumi et al., 2000) and in the Syrian Hamster and man, where the left coronary artery is absent, presenting only the branches originating from the aorta (Durán et al., 2006 and Ajayi et al., 2015).

The left coronary artery is divided into paraconal interventricular branch and circumflex branch in donkeys (Ozgel et al., 2004), North American beavers ((Bisaillon, 1981), rabbits (Dursun et al., 1996), crab-eating macaques (Buss et al., 1982; Mandarim and Hureau, 1986; TeofilovskiParapid et al., 1993; Shimada et al., 1994; Teofilovski-Parapid and Kreclovi, 1998), ruminants (Schummer et al., 1981; Ghoshal and Getty, 1986; Oliveira et al., 2013), spotted pacas (Ávila et al., 2009), porcupines (Atalar et al., 2003) and pigs (Moura-Junior et al., 2008), or it can trifurcate into another branch in rodents in a frequency up to $45 \%$ (Aikawa and Kawano, 1985; Sans Coma et al., 1993) and green monkey (Valentina et al., 2003). This branch can be named diagonal (Baptista et al., 1991; MouraJunior et al., 2008; Sahni et al., 2008; Oliveira et al., 2010; Oliveira et al., 2013), ramus marginalis sinister (Valentina et al., 2003), obtuse marginal artery (Durán et al., 2006) or ramus marginis concavi (Yuan et al., 2009).

The right coronary artery is presented with different patterns among species, which can have the subsinuosal interventricular branch in pigs and horses and in dogs and ruminants, the circumflex branch (Schummer et al., 1981; Ghoshal and Getty, 1986; Ozgel et al., 2004). In camels there can be the ramus cone arteriosi, which is directed to the arterial cone towards the cardiac apex (Yan et al., 2009).

Apart from the heart's importance to the organism function, Myrmecophaga tridactyla is included in the "vulnerable" category on the List of Brazilian Fauna Threatened Species (MMA 2003 and Medri and Mourão, 2008), being listed on the "Apendix II" of CITES (Brasil, 2009). Nowadays this species is included in the "vulnerable" category of The IUNC Red List of Threatened Species (Red..., 2012).

Given the great importance of this species and the need for comparative studies, this research describes the vascular architecture of the coronary arteries, aiming to establish a coronary pattern of the species.

\section{MATERIALS AND METHODS}

This study analized 12 adult Giant anteaters (Myrmecophaga tridactyla), 6 them were males and 6 females, weighing from 20 to 27,32kg. All animals were free-living and were donated by the Department of Wildlife Clinical and Surgical Care (SACCAS) of the Veterinary Hospital "Dr. Halim Atique" and properly sent to the Veterinary Anatomy Laboratory from the University Center of Rio Preto (UNIRP). The research had authorization of the Ethics Committee on Animal Use from the Faculty of Veterinary Medicine and Animal Science, University of Sao Paulo no 2583/2012.

The thoracic cavity was opened by a scalpel incision of the skin and muscles and removal of the sternum by rupturing the costochondral joints. Subsequently, the heart and lungs were identified. The set of lungs and heart was removed and after isolating the heart it was performed the injection of a latex substance ${ }^{1}$ colored with a specific pigment ${ }^{2}$ at the origin of both coronary arteries, then fixated in a $10 \%$ Formaldehyde solution for 72 hours. After this time, the coronary arteries were dissected, and the results found in each specimen were registered. The Nomina Anatomica Veterinária 
(2017) for the description of the anatomical structures.

\section{RESULTS}

In $50.0 \%$ of the animals studied the right coronary artery emerged through a single coronary ostium of the aorta emitting the intermediate branch, which continues under the arterial cone towards the cardiac apex, and the subsinuous interventricular branch, which had a path directed to the subsurface interventricular groove (Figure 1). In the other $50.0 \%$ the right coronary artery was absent, showing only its branches, the intermediate branch and subusinuosal interventricular branch emerging from the aorta (Figure 2A e 2B), taking the same trajectory. It always presented its trajectory superficial to the epicardium.

The left coronary artery has its trajectory upon the epicardium and presented, in $83.33 \%$ of the cases, its origin from the aorta in a single ostium, emitting the circumflex and paraconal interventricular branches (Figure 3). The circumflex branch ran through the coronary sulcus in cranial directon, when in the cranial border of the organ, emitted the left marginal artery. The paraconal interventricular branch coursed the paraconal interventricular sulcus ending at the cardiac apical incisure. This branch emitted during its trajectory the intermediate branch, which is more evident and several septal branches (Figure 4). In $16.66 \%$, the left coronary artery was not detected originating from the
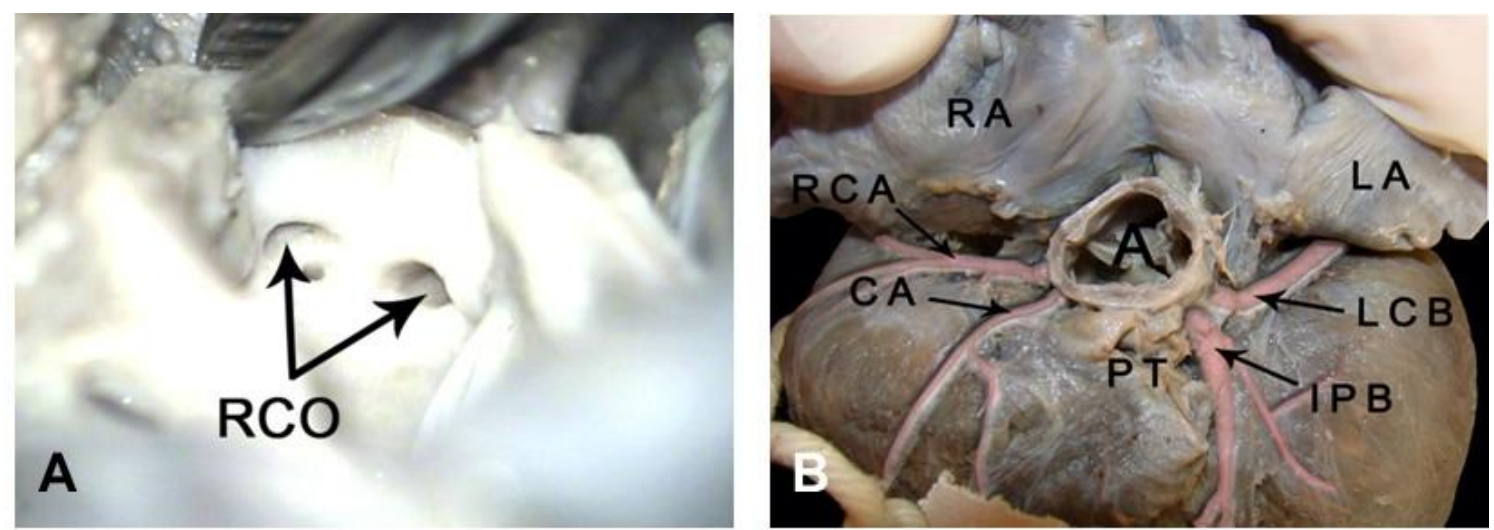

Figure 2. A) Photograph of the right coronary ostio ( $\mathrm{RCO})$ of the Giant Anteater, resulting in the right circumflex branch and the conal artery. (20X magnification). B) Photograph of the heart base of the giant anteater (Myrmecophaga tridactyla). We observe the right auricle (RA), left auricle (LA), aorta (A), pulmonary trunk (PT), right coronary artery (RCA), conal artery (CA), interventricular paraconal branch (IPB) and left circumflex branch (LCB). 


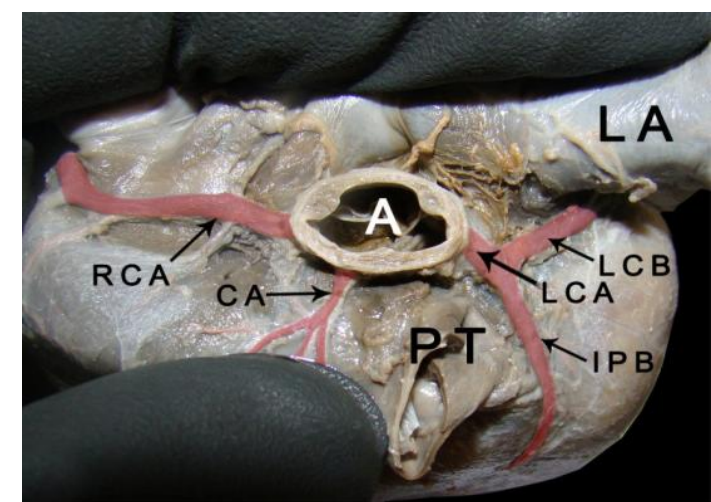

Figure 3. Photograph of the heart base of the Giant Anteater. We observe the left auricle (LA), aorta (A), pulmonary trunk (PT), right coronary artery (RCA), conal artery (CA), left coronary artery (LCA), interventricular paraconal branch (IPB) and left circumflex branch (LCB).

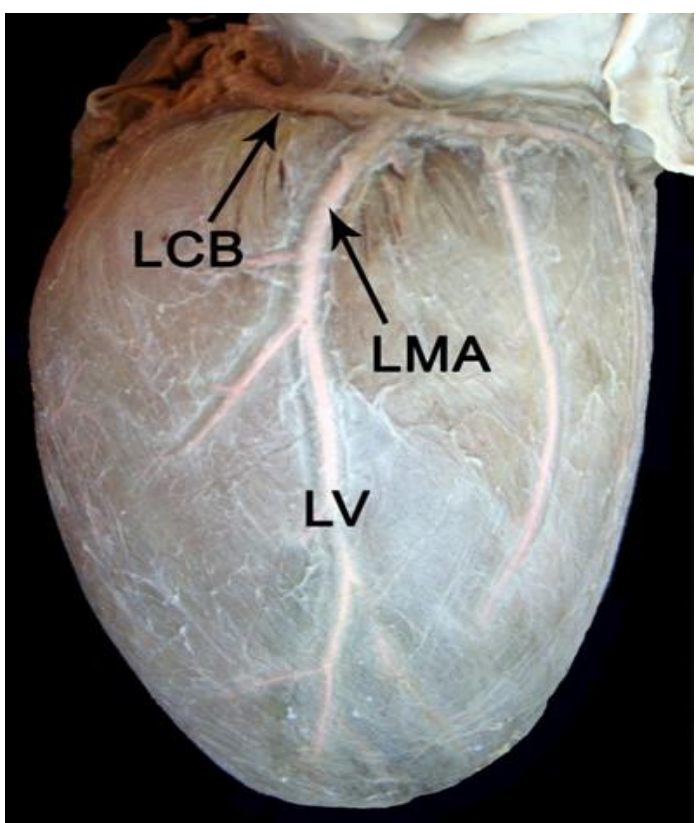

Figure 4. Photograph of the cranial face of the heart of the Giant Anteater. We observe the left circumflex branch (LCB) starting the left marginal artery (LMA), which goes towards the cardiac apex (LV).

\section{DISCUSSION}

The right and left coronary arteries were present superficially to the epicardium and it was not observed deepening vessels in any of the animals as related in other species Sans Coma et al. (1993), Bezerra et al. (1985), Machado et al. (2002). They are the heart suppliers, beginning in the right and left aortic sinuses, therefore, occupying the atrioventricular and interventricular coronary sulcus (Schummer et al., 1981; Ghoshal and Getty, 1986; Valentina et al., 2003; Oliveira et al., 2013) including in giant anteaters.

The right coronary artery was observed with its emission from the aorta as reported by Banchi (1904), Abramson and Eisenberg (1935), Schlesinger et al. (1949), Ghoshal and Getty, (1986), Vicentini et al. (1991), Machado et al. (2002), Pérez and Lima (2006), Rade et al. (2006), Olabu et al. (2007), Moura-Junior et al. (2008), Yuan et al. (2009), Agustín et al. (2010)), Tenani et al. (2010), Srour (2011) and Oliveira et al. (2013). It is worth mentioning this statement was evidenced in $50 \%$ of the animals studied. In $16.66 \%$ of the cases, in Giant Anteaters, the left coronary artery was absent, presenting only its paraconal interventricular and circumflex branches, a fact also observed by Vicentini (1991), who evidenced in guinea pigs four branches originating from the aorta, and by Tenani et al. (2010) in capybaras, where in 3.3\% of the cases the paraconal interventricular and circumflex branches of the left coronary artery have their origin directly from the aorta. In $50 \%$ of the Giant Anteaters, the right coronary artery presented only its branches emerging from the aorta, this variation was also reported in other mammal species, like the Syrian hamster (Durán et al., 2006) and even in humans (Ajayi et al., 2014). This variation, as to the presence, was evidenced in Syrian hamster with a lot of consanguinity (Durán et al., 2006), which could also happen in Giant Anteaters, considering they are found in the "vulnerable" list of animals. The subsinuosal interventricular branch, which is one of the branches of the right coronary artery, is similar to those of swines and equines (Schummer et al., 1981 and Ghoshal and Getty, 1986) donkeys (Ozgel et al., 2004) and Angora rabbits (Bahar et al., 2007).

The other branch was named intermediate branch due to the fact of the Nomina Anatomica Veterinária (2017) report the presence of the branch in the left coronary artery, and, in Giant Anteaters, this branch presents itself basically at the same position of this branch of the left coronary artery. This vessel was reported in Angora rabbits (Bahar et al., 2007), also belonging to the right coronary artery as the $r$. 
intermedius atrii desxtri, in donkeys (Ozgel et al., 2004) as the ramus marginalis convexi and in camels Yuan et al. (2009) as the ramus cone arteriosi. In carnivores, sometimes an accessory right coronary artery emerged from the aorta, close to the origin of the right coronary artery, and that normally ended around the arterial cone (Ghoshal and Getty, 1986). The same observation was found in humans (Schlesinger et al. 1949), however, describing the existence of a third coronary artery, the conal artery, with direct origin from the aorta or with its origin in the right coronary artery. As reported above, in 50\% of the Giant Anteaters, it was evidenced the intermediate branch emerging directly from the aorta. This artery has the function of nurturing the arterial cone region, besides being an alternative route of blood supply (Schlesinger et al. 1949; Vicentini et al., 1991; Olabu et al., 2007; Yuan et al., 2009; Agustín et al., 2010 and Srour, 2011). In the present study, it was observed in $100 \%$ of the hearts from the Giant Anteaters the presence of the intermediate branch, where $50 \%$ presented its own coronary ostium from the aorta and in the other $50 \%$ with its origin from a common ostium with the right coronary artery.

The left coronary artery was present in $83,66 \%$ of the cases in Giant Anteaters, dividing itself in circumflex and paraconal interventricular branches as well as in donkeys (Ozgel et al., 2004), guinea pigs (Vicentini et al., 1991), capybaras (Tenani et al., 2010), North American beavers (Bisaillon, 1981), camels (Yuan et al., 2009), rabbits (Dursun et al., 1996); dolphins (Pérez and Lima 2006), monkeys (Abramson and Eisenberg 1935; Buss et al., 1982; Mandarim and Hureau, 1986; Teofilovski-Parapid et al., 1993; Shimada et al., 1994; Teofilovski-Parapid and Kreclovi 1998; Rade et al., 2006), spotted pacas (Ávila et al., 2009), porcupines (Atalar et al., 2003 and Srour, 2011), ruminants (Schummer et al., 1981; Ghoshal and Getty, 1986; Machado et al., 2002; Oliveira, et al., 2013) and swines (Moura-Junior et al., 2008). In $16.66 \%$ of the cases, this vessel did not present its origin from the aorta, but only its branches, a fact that has not been reported in literature. It was not observed absence of the left coronary artery, as reported in Syrian hamsters (Durán et al., 2006) and humans (Ajayi et al., 2015), or even the artery presenting itself duplicated (Kareem et al., 2014).
As for the fact of the heart presenting a single vessel responsible for its supply such as in calves (Cervený and Kaman, 1963), Syrian hamsters (Durán et al., 2006) or even in humans Koizumi et al. (2000), this aspect was not observed.

Regarding the coronary pattern, considering the classification proposed by Banchi (1904), for the present research, $91.66 \%$ of the Giant Anteaters presented the normal or balanced coronary pattern, where the right coronary artery provides the subsinuosal interventricular branch, and the left coronary artery provides the paraconal interventricular branch, a feature also observed in spotted pacas (Ávila et al., 2009), in hearts of equines, swines and also, in $50.0 \%$ of the cats (Marques, 1962). In swines, the balanced pattern was the dominant (Pinto et al., 2016). In $8.33 \%$ of the Giant Anteaters, the left coronary artery provides both the paraconal interventricular and the subsinuosal interventricular branches, therefore characterizing the type A coronary pattern or left, also evidenced in most ruminants, dogs, in 50\% of the cats (Marques, 1962), in capybaras (Tenani et al., 2010) and in the dolphin (Pérez and Lima, 2006).

There is a notable need of more profound studies in animals, since some of them could be presented as coronary model for studies, as already demonstrated in monkeys (Valentina et al., 2003) and in bovines (Oliveira et al., 2013).

\section{ACKNOWLEDGMENTS}

The Research Foundation of the State of São Paulo - FAPESP by financial incentive of scientific initiation scholarship process: 09/54025-9.

\section{REFERENCES}

ABRAMSON, D.I.; EISENBERG, I.J. The coronary blood supply in the Rhesus monkey. $J$. Anat., v.69, p.520-525, 1935.

AGUSTIN J.A.; MARCOS-ALBERCA, P.; HERNÁNDEZ-ANTOLÍN, R. et al. Circulación colateral de arteria conal a descendente anterior: valoración con tomografía coronaria multidetector. Rev. Esp. Cardiol., v.63, p.347-51, 2010. 
AIKAWA, E.; KAWANO, J. Genetic basis of the "posterior" coronary artery in mice. In: INTERNATIONAL ANATOMICAL CONGRESS, 12., 1985, London. Proceedings... London: [s.n.], 1985. Abstracts, p.4.

AJAYI, N.O.; LAZARUS, L.; VANKER, E.A.; SATYAPAL, K.S. Absent left main coronary artery with variation in the origin of its branches in a South African population. Anat. Histol. Embryol., v.44, p.81-85, 2015.

ATALAR, Ö.; YILMAZ, S.; BURMA, O.; ILKAY, E. The macroanatomical investigations on the aortic arch in porcupines (Hystrix cristata). Anat. Histol. Embryol., v.32, p.367369, 2003.

ÁVILA, B.H.P.; MACHADO, M.R.F.; GERBASI, S.H.B.; OLIVEIRA, F.S. As artérias coronárias da paca (Agouti paca Linnaeus, 1766). Biotemas, v.22, p.159-162, 2009.

BAHAR, S.; OZDEMIR. V.; EKEN, E.; TIPIRDAMAZ, S. The distribution of the coronary arteries in the Angora rabbit. Anat. Histol. Embryol., v.36, p.321-327, 2007.

BANCHI, A. Morfologia delle arteriae coronariae cordis. Arch. Ital. Anat. Embriol., v.3, p.164, 1904.

BAPTISTA, C.A.C.; DIDIO, L.J.A.; PRATES, J.C. Types of division of the left coronary artery and the ramus diagonalis of the human heart. Jpn. Heart J., v.32, p.323-335, 1991.

BERG, R. Beitrag zur phylogenese des verhaltens der koronarterien zum myokard beim hausschwein (Sus scrofa domesticus). Anat. Anz., v.115, p.184-192, 1964.

BEZERRA, A.J.; DIDIO, A.S.; DIDIO, L.J. Bridges of myocardium over branches of the coronary arteries in Camelus dromedarius. Arch. Anat. Ital. Embriol., v.90, n.4, p.267-274, 1985.

BISAILLON, A. Gross anatomy of the cardiac blood vessels in the North American beaver (Castor canadensis). Anat. Anz., v.150, n.3, p.248-258, 1981.

BRASIL. Ministério do Meio Ambiente. Lista Nacional das Espécies da Fauna Brasileira Ameaçadas de Extinção. 2003. Brasília.
BUSS, D.D.; HYDE, D.M.; POULOS, P.W. Coronary artery distribution in bonnet monkeys (Macaca radiata). Anat. Rec., v.203, p.411-417, 1982.

CERVENÝ, C.; KAMAN, J. Common stem of coronary arteries in a calf. Anat. Anz., v.113, p.29, 1963.

COPELAND, J.G.; SMITH, R.G.; ARABIA, F.A. et al. Cardiac replacement with a total artificial heart as a bridge to transplantation. $N$. Engl. J. Med., v.351, p.859-867, 2004.

CORBAN, M.T.; HUNG, O.Y.; ESHTEHARDI, $\mathrm{P}$. et al. Myocardial bridging: contemporary understanding of pathophysiology with implications for diagnostic and therapeutic strategies. J. Am. Coll. Cardiol., v.63, p.23462355, 2014.

DURÁN, A.C.; FERNÁNDEZ-GALLEGO, T.; FERNÁNDEZ, B. et al. Anomalous origin of the left coronary artery from the right side of the aortic valve in Syrian hamsters (Mesocricetus auratus). J. Pathol., v.134, p.290-296, 2006.

DURSUN, N.; YILDIZ, D.; KABAK, M. Yeni Zelanda tavsaninda (Oryctolagus cuniculus L.) septum interventriculare'nin arteriel vaskularizasyonu. Ankara Oniv. Vet. Fak. Derg., v.43, p.391-395,1996.

GHOSHAL, N.G. Coração e artéria das ruminantes. GETTY, R. Sisson/Grossman Anatomia dos animais domésticos, Rio de Janeiro: Guanabara Koogan, 1986. p. 1847-1848.

GHOSHAL, N.G.; GETTY, R. Coração e artérias do carnívoro. In: GETTY, R. Sisson/Grossman anatomia dos animais domésticos. Rio de Janeiro: Guanabara Koogan, 1986. p.1497-1550.

HANES, D.W.; WONG, M.L.; CHANG, C.J. et $a l$. Embolization of the first diagonal branch of the left anterior descending coronary artery as a porcine model of chronic trans-mural myocardial infarction. J. Transl. Med., v.13, p.187, 2015.

KAREEM, H.; DEVASIA, T.; PRASAD, R.; PAI, U. Dual left anterior descending artery circulation: a rare anomaly of the coronary arteries: case reports. BMJ, v.2014, p.bcr2014205053. 
KOIZUMI, M.; KAWAI, K.; HONMA, S.; KODAMA, K. Anatomical study of a left single coronary artery with special reference to the various distribution patterns of bilateral coronary arteries. Ann. Anat. Anat. Anz., v.182, p.549-557, 2000.

MACHADO, M.R.F.; BORGES, E.M.; OLIVEIRA, F.S. et al. Intramyocardial course of the coronary arteries in the marsh deer (Blastocerus dichotomus). Braz. J. Vet. Res. Anim. Sci., v.39, p.285-287, 2002.

MANDARIM-DE-LACERDA, C.A.; HUREAU, U.J. Arterial vascularization of the sino-atrial and atrio-ventricular nodes and frequency of coronary artery branches in Papio erxleben, 1777. Folia Primatol. Int. J. Primatol., v.46, p.65-69, 1985.

MARQUES, M.P.R. Alguns aspectos morfológicos comparativos do coração dos mamíferos domésticos. Lisboa: Tipografia Nunes, 1962. p.320.

MEDRI, I.M.; MOURÃO, G. Myrmecophaga tridactyla (Tamanduá-bandeira). Livro vermelho da fauna brasileira ameaçada de extinção. Brasília: MMA, 2008. p.711-713.

MORGAN, J.A.; JOHN, R.; RAO, V. et al. Bridging to transplant with the Heart Mate left ventricular assist device: the columbia presbyterian 12-year experience. J. Thoracic Cardiovasc. Surg., v.127, p.1309-1316, 2004.

MOURA-JUNIOR, P.C.M.; VIEIRA, T.H.M.; VIEIRA, S.R.C. et al. Estudo anatômico das artérias coronárias de suínos Landrace. Pesqui. Vet. Bras., v.28, p.103-107, 2008.

OLABU, B.O.; SAIDI, H.S.; HASSANALI, J.; OGENG'O, J.A. Prevalence and distribution of the third coronary artery in Kenyans. Int. J. Morphol., v.25, p.851-854, 2007.

OLIVEIRA, C.L.; DORNELAS, D.; CARVALHO, M. et al. Anatomical study on coronary arteries in dogs. Eur. J. Anat., v.14, p.14, 2010.

OLIVEIRA, M.C., HERNANDEZ, J.M.F.; ABIDU-FIGUEIREDO, M. Morfometria cardíaca e distribuição das artérias coronárias em bovinos mestiços. Biotemas, v.26, n.2, p.199207, 2013.
OZGEL, O.; HALIGUR, A.; DURSUN, A.; KARAKURUM, E. The macroanatomy of coronary arteries in donkeys (Equus asinus L.). Anat. Histol. Embryol., v.33, p.278-283, 2004.

PÉREZ, W.; LIMA, M. Anatomia cardíaca de Pontoporia blainvillei. Int. J. Morphol., v.24, p.351-356, 2006.

PINTO, M.G.; FAVARON, P.O.; ALCÂNTARA, D. et al. Padrões de vascularização arterial em corações de suínos. Pesqui. Vet. Bras., v.36, p.417-422, 2016.

RADE, W.; PEREIRA, W.F.; CARNEIRO, F.O. Origem, trajeto, distribuição e ramificações dos ramos ventriculares da artéria coronária direita no macaco prego (Cebus apella). Biosci. J., v.22, p.133-137, 2006.

RED list of threatened species. Version 2011.1. Gland: IUCN, 2012.

SAHNI, D.; KAUR, G.D.; JIT, H.; JIT, I. Anatomy and distribution of coronary arteries in pig in comparison with man. Indian J. Med. Res., v.127, p.564-570, 2008.

SANS COMA, V.; ARQUÉ, J.M.; DURÁN, A.C. et al. The coronary arteries of the Syrian hamster, Mesocricetus auratus (Waterhouse 1839). Ann. Anat., v.175, p.53-57, 1993

SCHLESINGER, M.J.; ZOLL, P.M.; WESSLER, S. The conus artery: a third coronary artery. Am. Heart J. v.38, p.823-836, 1949.

SCHUMMER, A.; WILKENS, H.; VOLLMERHAUS, B.; HABERMEHL, K.H. The circulatory system, the skin, and the cutaneous organs of the domestic mammals. In: NICKEL, R.; SCHUMMER, A.; SEIFERLE, E. (Eds.). The Anatomy of the domestic animals. Berlin: Paul Parey, 1981. p.52-53.

SHIMADA, K.; SATO, I.; INOKUCHI, S.; TEOFILOVSKI-PARAPID, G. Distribution of the coronary arteries in monkey (Macaca fuscate, Cercopithecus aethiops). In: FEDERATIVE INTERNATIONAL CONGRESS OF ANATOMY, 14., Lisbon. Proceedings... Lisbon: [s.n.], 1994. Abstract, p.288. 
SROUR, H.A. Origin and ventricular ramifications of the left coronary artery in capuchin monkey (Cebus apella). 2011. 36f. Dissertação (Mestrado em Ciências Agrárias) Universidade Federal de Uberlândia, Uberlândia, 2011.

TAYLOR, D.O.; EDWARDS, L.B.; BOUCEK, M.M.; TRULOCK, E.P. et al. Registry of the International Society for Heart and Lung Transplantation: twenty-fourth official adult heart transplant report. 2007. J. Heart Lung Transpl., v.26, p.769-781, 2007.

TENANI, S.C.; MELO, A.P.F.; RODRIGUES, R.F. Estudo da vascularização arterial em corações de capivara (Hydrochaeris hydrochaeris-Carleton, MD 1984). Braz. J. Vet. Res. Anim. Sci., v.47, p.203-207, 2010.

TEOFILOVSKI-PARAPID, G.; KREDOVITĆ, G. Coronary artery distribution in Macaca fascicularis (Cynomolgus). Lab. Anim., v.32, p.200-205, 1998.
TEOFILOVSKI-PARAPID, G.; NIKOLIĆ, V.; RANKOVIĆ, A. et al. Koronarne arterije majmuna Macaca fascicularis. Srp. Arh. Celok. Lek., v.121, p.117-119, 1993.

VALENTINA, N.; SLOBODAN, M.; MALIŠ, M.; GORDANA, T.P.; STANKOVIĆ, I. Distribution of left coronary artery branches in the african green monkey. Acta Vet., v.53, p.139$150,2003$.

VETERINARIA, Nomina anatomica. International Committee on Veterinary Gross Anatomical Nomenclature (ICVGAN). 6.ed. revised. Nomina Anatomica Veterinaria, 2017.

VICENTINI, C.A.; ORSI, A.M.; DIAS, S.M. Anatomical observations of the coronary artery vascularization in the guinea pigs (Cavia porcellus, L.). Anat. Anz., v.172, p.209-212, 1991.

YUAN, G.; MA, J.; YE, W.; BAI, Z.; WANG, J. Macroanatomy of coronary arteries in Bactrian camel (Camelus bactrianus). Vet. Res. Commun., v.33, p.367-377, 2009. 